\title{
Efficacy of Nyagrodh Twak Lepa in Honey bee sting: In-vivo study
}

\author{
Research Article
}

\begin{abstract}
Amrit Malik1* ${ }^{*}$ Chinky Goyal2, Abhiram S P3 , Gramopadhye N G4
1. Associate Professor, Department of Agad Tantra, 2. Associate Professor and HOD, Department of Rasa Shastra \& Bhaishjya Kalpana, 3. Assistant Professor, Department of Agad Tantra, Shri Dhanwantry Ayurvedic College and Hospital, Chandigarh. India.

4. Professor \& HOD, Dept. of Agad Tantra, Yashwant Ayurvedic College, PGT\&RC, Kodoli, Maharashtra.
\end{abstract}

\begin{abstract}
Introduction- As Acharya Charaka has explained the local application of Kshirivruksha Twak to cure all types of keeta visha, hence Nyagrodh (Ficus benghalensis L.) Twak Lepa with water as base is selected as Trial drug on Apis Cerana Indica bee sting poisoning. Material and Methods- An in-vivo study on albino mice to know the efficacy of trial drug has been planned after animal ethical clearance. 18 albino mice were prorated into three groups with 6 animals in each group viz. Control group, Trial drug (Nyagrodh Twak Lepa Churna) group and Standard drug (Beclomethasone Dipropionate $0.025 \% \mathrm{w} / \mathrm{w}$ ) group. 6 stings were given to each mice and 3 stings were removed after sting operation. All mice were observed for allergic reactions viz. erythema, scaling, fissures, oedema and mortality for a period of 7 days. Histo-pathological changes were also noted after completion of study. Statistical analysis was done using Paired t test. Results- Results revealed that Trial drug had worked more efficiently on Erythema and Oedema while Standard drug worked more efficiently on Scaling and Fissure. Histo-pathology showed that wound healed with Nyagrodh twak lepa and Standard drug have shown almost similar changes while wound in control group showed extensive areas of necrosis. Conclusion- Present study suggests that both Nyagrodh and Beclomethasone can be used in Honey bee sting poisoning but as Nyagrodh being a religious tree can be easily identified by a common man, it can be employed as preliminary treatment for the same before reaching hospital.
\end{abstract}

Key Words: Honey bee sting, Lepa, Nyagrodh twak, Vata Vruksha, Bee sting poisoning.

\section{Introduction}

Insect bite is very common and usually it is ignored. Cases of honey bee stings are very common in clinical practice. Most of these bites are less harmful and negligible but sometimes poisonous bites could lead to various complications i.e anaphylactic shock. In Sushruta Samhita vast description of Keeta (insects) is given in Kalpa Sthana.(1)

There are millions of insects, however Honey bee is among few insects which are very important for human beings and became a part of their culture. Despite the evidence of an enduring reverence for the Honey bee, human beings have an uneasy relationship with it. Honey bees are absolutely essential for the production of agricultural crops as they pollinate $1 / 3^{\text {rd }}$ of what we eat. Apiculturists are easily victimized by bee stings. Most of them die because of anaphylactic shock. Hence it is necessity of time to search for such a drug which is easily available and easy to use even in remote places.

\section{* Corresponding Author:}

\section{Amrit Malik}

Associate Professor,

Department of Agad Tantra,

Shri Dhanwantry Ayurvedic College and Hospital,

Chandigarh. India.

Email Id: dramritmalik@gmail.com
Wasps, bees and hornets secrete a poisonous fluid known as Apitoxin which is a bitter colorless liquid and is hemolytic and neurotropic in toxic amounts. The main component of the venom is a complex amalgamation of proteins, that leads to local inflammation and act as an anticoagulant. As it is impossible to study all the insects in a single study, therefore for thorough and specific study, here only one of the Makshika i.e. Madhumakshika is selected which comes under jangama visha.

Aacharya Charaka has explained the local application (Lepa) of kshirivruksha twak to cure all types of keeta visha,(2) hence Nyagrodh twak lepa is selected as local application on Apis Cerana Indica bee sting poisoning. Nyagrodh is (one of the panchkshri vruksha) considered as anti-inflammatory having properties of healing and coagulation.

\section{Aims and objectives}

Aim

To study the efficacy of Nyagrodh (Ficus benghalensis L.) twak lepa in Honey bee sting in Albino Mice.

\section{Objectives}

1. To study the toxic effect of Honey bee sting in Albino Mice according to the symptoms. 
2. To study the efficacy of Nyagrodh twak lepa according to signs of Honey bee sting in Albino Mice.

3. To study the efficacy of Nyagrodh twak lepa (local application) in Honey bee sting in Albino mice.

\section{Materials and methods \\ Test Sample}

Raw sample of Nyagrodh twak was collected from herbal garden and periphery of Yashwant Ayurvedic College PGTRC Kodoli, Kohlapur and was dried for 7 days under shade. Authentication of the same was done at Authorized laboratory of Vasanti Devi Patil Institute of Pharmacy, Kodoli, Kohlapur, Maharashtra.

\section{Preparation of Nyagrodh twak lepa}

Bark of Nyagrodh was grinded in a mixer and powdered, filtered through Sieve no. 120 to obtain fine light brown colored powder. In clean washed Petri dish 8 gm powder of Nyagrodh twak churna was taken and 5 $\mathrm{ml}$ water was added to it with the help of $5 \mathrm{ml}$ syringe. This mixture was mixed with the help of spatula and then slurry lepa was prepared. Each day fresh lepa was prepared for application.

\section{Experimental Study}

It was done in National Toxicology Centre, Pune Maharashtra as per the protocol approved by IAEC of NTC through research project no 249 and IEC approval number PGYACK/454/2012.(3)

\section{Table 1: Experimental Group Design}

\begin{tabular}{|l|l|r|} 
Group & Application & Mice \\
\hline 1-Control group & No application & 6 \\
\hline 2-S t a n d a r d & Beclomethasone dipropionate & 6 \\
group & $0.025 \%$ & \\
3-Trial group & Nyagrodh twak lepa & 6 \\
\hline
\end{tabular}

\section{Test Drug toxicity test}

Prior to the main study, test drug toxicity study was done for which 4 mice were selected $(2$ male and 2 female). These mice were not included in experimental study. Hair were removed from the back of mice by hair removing cream and Nyagrodh twak lepa was applied on the back of each mice and observed for 48 hours. No toxicity of Nyagrodh twak lepa was seen within stipulated period of 48 hours showing test drug to be safe.

\section{Calculation of dose of Apis Cerena Indica}

- It was done by giving stings in increasing number to different mice (which were not included in study) and observed for reaction.

- Mouse receiving 32 stings died after 4 days.

- Sublethal dose is selected to know the anti-toxic effect of Nyagrodh twak lepa.

- Hence six stings are selected to be given in each Albino mice.

\section{Method}

Table 2: Animal Housing and Feeding Conditions

Animal species

used

Strain

Source of animal

Sex of animal

No. of animals

Average weight

Diet

Water

Room temperature

Relative humidity

Light cycle

Period of

Acclimatization

All 18 mice (50\% male and 50\% female) were prepared for experiment. For removing hair a strong depilatory (hair removal) cream was used at the back of each albino mice. Only desired area on the back was depilated on each mice.

Foraged bees colony was selected for the experiment. Honey bees were collected from National Toxicology Centre, Pune.

For identification of groups of male and female mice, they were stained (yellowish) with picric acid which remains for three to four weeks.

Each mice was given stings one by one at their back maintaining a safe distance between two stings.

After sting operation, out of six stings in each albino mice three stings were removed and another three stings were kept as it is.

After giving stings all mice were observed for 1 hour for toxic signs and symptoms and mortality, up to a period of 7 days.

Table 3: For experimental rating of skin reactions following observations were noted:

(A) Erythema

Skin Reaction Rating

\begin{tabular}{|l|l|}
\hline Slight, spotty $\backslash$ diffuse & 1 \\
\hline moderate uniform redness & 2 \\
\hline Intense & 3 \\
\hline Fiery red with edema or epidermal & 4 \\
\hline
\end{tabular}

(B) Scaling

\begin{tabular}{l|l} 
dryness shiny & 1
\end{tabular}

fine scale 2

Moderate 3

\begin{tabular}{l|l} 
severe with large flakes & 4
\end{tabular}

(C) Fissures

fine cracks 1

single / multiple broader fissure 2

made cracks with hemorrhage or 3

(D) Oedema

No oedema 0

Very slight oedema 1

Slight oedema( edges of area well 2

Moderate oedema (raised app $1 \mathrm{~mm}$ ) 3

Severe oedema ( raised more than 1 $\mathrm{mm} \&$ extending beyond area of

(3)

(20)

1

2

3

\begin{tabular}{l|}
0 \\
1 \\
2 \\
3 \\
4 \\
\hline
\end{tabular}




\section{Observations}

Signs and symptoms were observed for 7 days in all the three groups.

Table 4: Observation table for Erythema in Trial group

\begin{tabular}{|c|c|c|c|c|c|c|c|c|c|}
\hline Sr. No. & Animal Marking & Sex & Day 1 & Day 2 & Day 3 & Day 4 & Day 5 & Day 6 & Day 7 \\
\hline 1 & H & M & 3 & 2 & 2 & 1 & 1 & 1 & 0 \\
\hline 2 & T & M & 3 & 3 & 2 & 1 & 2 & 1 & 1 \\
\hline 3 & W & M & 2 & 2 & 2 & 1 & 2 & 1 & 1 \\
\hline & H & F & 3 & 2 & Dead & - & - & - & - \\
\hline 5 & T & F & 2 & 2 & 2 & 1 & 1 & 1 & 0 \\
\hline 6 & W & F & 2 & 2 & 2 & 1 & 1 & 1 & 1 \\
\hline
\end{tabular}

H-Head Marking, T-Tail Marking, W-White (No Marking)

Table 5: Observation Table for Erythema in Standard group

\begin{tabular}{|c|c|c|c|c|c|c|c|c|c|}
\hline Sr. No. & Animal Marking & Sex & Day 1 & Day 2 & Day 3 & Day 4 & Day 5 & Day 6 & Day 7 \\
\hline 1 & H & M & 2 & 2 & 2 & 1 & 1 & 1 & 0 \\
\hline 2 & LH & M & 3 & 2 & 2 & 1 & 1 & 1 & 1 \\
\hline 3 & W & M & 2 & 2 & 2 & 1 & 1 & 1 & 1 \\
\hline 4 & H & F & 3 & 2 & 2 & 2 & 2 & 2 & 2 \\
\hline 5 & LH & F & 3 & 3 & Dead & - & - & - & - \\
\hline 6 & W & F & 2 & 2 & 2 & 1 & 1 & 1 & 0 \\
\hline
\end{tabular}

Table 6: Observation Table for Erythema in Control group

\begin{tabular}{|c|c|c|c|c|c|c|c|c|c|}
\hline Sr. No. & Animal Marking & Sex & Day 1 & Day 2 & Day 3 & Day 4 & Day 5 & Day 6 & Day 7 \\
\hline 1 & H & M & 2 & 2 & 2 & 2 & 1 & 1 & 1 \\
\hline 2 & RH & M & 3 & 3 & Dead & - & - & - & - \\
\hline 3 & W & M & 2 & 2 & 2 & 2 & 2 & 2 & 2 \\
\hline 4 & H & F & 2 & 2 & 2 & 2 & 1 & 1 & 1 \\
\hline 5 & RH & F & 3 & 3 & Dead & - & - & - & - \\
\hline & W & F & 1 & 1 & 1 & 1 & 1 & 1 & 1 \\
\hline
\end{tabular}

H-Head Marking, RH-Right Hind Limb Marking, W-White (No Marking)

Table 7: Observation Table for Scaling in Trial group

\begin{tabular}{|c|c|c|c|c|c|c|c|c|c|}
\hline Sr. No. & Animal Marking & Sex & Day 1 & Day 2 & Day 3 & Day 4 & Day 5 & Day 6 & Day 7 \\
\hline 1 & H & M & 2 & 2 & 2 & 1 & 1 & 1 & 1 \\
\hline 2 & T & M & 2 & 2 & 2 & 2 & 1 & 1 & 0 \\
\hline 3 & W & M & 3 & 3 & 2 & 2 & 2 & 2 & 2 \\
\hline 4 & H & F & 2 & 2 & Dead & - & - & - & - \\
\hline 5 & T & F & 3 & 2 & 2 & 2 & 1 & 1 & 0 \\
\hline 6 & W & F & 3 & 2 & 2 & 2 & 1 & 1 & 1 \\
\hline
\end{tabular}

Table 8: Observation Table for Scaling in Standard group

\begin{tabular}{|c|c|c|c|c|c|c|c|c|c|}
\hline Sr. No. & Animal Marking & Sex & Day 1 & Day 2 & Day 3 & Day 4 & Day $\mathbf{5}$ & Day 6 & Day 7 \\
\hline 1 & H & M & 1 & 1 & 1 & 1 & 1 & 1 & 1 \\
\hline 2 & LH & M & 1 & 1 & 1 & 1 & 1 & 1 & 0 \\
\hline 3 & W & M & 2 & 2 & 1 & 1 & 1 & 1 & 0 \\
\hline & H & F & 3 & 3 & 2 & 2 & 2 & 2 & 2 \\
\hline 5 & LH & F & 2 & 1 & Dead & - & - & - & - \\
\hline 6 & W & F & 2 & 2 & 1 & 1 & 1 & 1 & 0 \\
\hline
\end{tabular}

Table 9: Observation Table for Scaling in Control group

\begin{tabular}{|c|c|c|c|c|c|c|c|c|c|}
\hline Sr. No. & Animal Marking & Sex & Day 1 & Day 2 & Day 3 & Day 4 & Day $\mathbf{5}$ & Day 6 & Day 7 \\
\hline 1 & H & M & 1 & 1 & 1 & 1 & 1 & 1 & 1 \\
\hline 2 & RH & M & 2 & 2 & Dead & - & - & - & - \\
\hline 3 & W & M & 3 & 3 & 2 & 2 & 2 & 2 & 2 \\
\hline 4 & H & F & 2 & 2 & 2 & 2 & 2 & 2 & 2 \\
\hline 5 & RH & F & 3 & 3 & Dead & - & - & - & - \\
6 & W & F & 2 & 2 & 2 & 1 & 1 & 1 & 1 \\
\hline
\end{tabular}

Table 10: Observation Table for Fissure in Trial group

\begin{tabular}{|c|c|c|c|c|c|c|c|c|c|}
\hline Sr. No. & Animal Marking & Sex & Day 1 & Day 2 & Day 3 & Day 4 & Day 5 & Day 6 & Day 7 \\
\hline 1 & H & M & 1 & 1 & 1 & 1 & 0 & 0 & 0 \\
\hline 2 & T & M & 2 & 2 & 2 & 2 & 2 & 2 & 2 \\
\hline 3 & W & M & 3 & 3 & 2 & 2 & 1 & 1 & 1 \\
\hline 4 & H & F & 2 & 2 & Dead & - & - & - & - \\
\hline 5 & T & F & 1 & 1 & 1 & 1 & 0 & 0 & 0 \\
\hline 6 & W & F & 3 & 3 & 3 & 2 & 1 & 1 & 1 \\
\hline
\end{tabular}




\section{Table 11: Observation Table for Fissure in Standard group}

\begin{tabular}{|c|c|c|c|c|c|c|c|c|c|}
\hline Sr. No. & Animal Marking & Sex & Day 1 & Day 2 & Day 3 & Day 4 & Day 5 & Day 6 & Day 7 \\
\hline 1 & H & M & 2 & 2 & 2 & 1 & 1 & 1 & 1 \\
\hline 2 & LH & M & 2 & 2 & 2 & 1 & 1 & 1 & 1 \\
\hline 3 & W & M & 1 & 1 & 1 & 1 & 1 & 1 & 0 \\
\hline 4 & H & F & 1 & 1 & 1 & 1 & 1 & 1 & 1 \\
\hline 5 & LH & F & 2 & 2 & Dead & - & - & - & - \\
\hline 6 & W & F & 1 & 1 & 1 & 1 & 1 & 1 & 0 \\
\hline
\end{tabular}

Table 12: Observation Table for Fissure in Control group

\begin{tabular}{|c|c|c|c|c|c|c|c|c|c|}
\hline Sr. No. & Animal Marking & Sex & Day 1 & Day 2 & Day 3 & Day 4 & Day 5 & Day 6 & Day 7 \\
\hline 1 & H & M & 1 & 1 & 1 & 1 & 1 & 1 & 1 \\
\hline 2 & RH & M & 2 & 2 & Dead & - & - & - & - \\
\hline 3 & W & M & 1 & 1 & 1 & 1 & 1 & 0 & 0 \\
\hline 4 & H & F & 2 & 2 & 2 & 2 & 2 & 2 & 2 \\
\hline 5 & RH & F & 2 & 1 & Dead & - & - & - & - \\
\hline 6 & W & F & 1 & 1 & 1 & 1 & 1 & 1 & 1 \\
\hline
\end{tabular}

Table 13: Observation Table for Edema in Trial group

\begin{tabular}{|c|c|c|c|c|c|c|c|c|c|}
\hline Sr. No. & Animal Marking & Sex & Day 1 & Day 2 & Day 3 & Day 4 & Day 5 & Day 6 & Day 7 \\
\hline 1 & H & M & 2 & 1 & 1 & 1 & 1 & 1 & 1 \\
\hline 2 & T & M & 2 & 2 & 2 & 2 & 2 & 2 & 2 \\
\hline 3 & W & M & 3 & 2 & 2 & 2 & 2 & 2 & 2 \\
\hline 4 & H & F & 2 & 1 & Dead & - & - & - & - \\
\hline 5 & T & F & 4 & 3 & 3 & 3 & 3 & 3 & 3 \\
\hline 6 & W & F & 3 & 2 & 2 & 2 & 2 & 2 & 2 \\
\hline
\end{tabular}

Table 14: Observation Table for Edema in Standard group

\begin{tabular}{|c|c|c|c|c|c|c|c|c|c|}
\hline Sr. No. & Animal Marking & Sex & Day 1 & Day 2 & Day 3 & Day 4 & Day 5 & Day 6 & Day 7 \\
\hline 1 & H & M & 1 & 1 & 1 & 1 & 1 & 1 & 1 \\
\hline 2 & LH & M & 2 & 2 & 2 & 1 & 1 & 1 & 1 \\
\hline 3 & W & M & 3 & 3 & 3 & 2 & 2 & 2 & 2 \\
\hline 4 & H & F & 3 & 3 & 2 & 2 & 2 & 2 & 2 \\
\hline 5 & LH & F & 2 & 1 & Dead & - & - & - & - \\
\hline 6 & W & F & 2 & 2 & 2 & 2 & 1 & 0 & 0 \\
\hline
\end{tabular}

Table 15: Observation Table for Oedema in Control group

\begin{tabular}{|c|c|c|c|c|c|c|c|c|c|}
\hline Sr. No. & Animal Marking & Sex & Day 1 & Day 2 & Day 3 & Day 4 & Day 5 & Day $\mathbf{6}$ & Day 7 \\
\hline 1 & H & M & 1 & 1 & 1 & 1 & 1 & 0 & 0 \\
\hline 2 & RH & M & 2 & 2 & Dead & - & - & - & - \\
\hline 3 & W & M & 2 & 2 & 2 & 2 & 2 & 2 & 2 \\
\hline 4 & H & F & 4 & 4 & 3 & 3 & 3 & 3 & 3 \\
\hline 5 & RH & F & 3 & 3 & Dead & - & - & - & - \\
\hline & W & F & 2 & 2 & 2 & 1 & 1 & 1 & 1 \\
\hline
\end{tabular}

$\mathrm{M}=$ Male, $\mathrm{F}=$ Female, $0=$ No Oedema, $\mathrm{H}=$ Head marking, $\mathrm{RH}=$ Right hind limb, $\mathrm{W}=$ white (no marking), $\mathrm{LH}=\mathrm{Left}$ Hind Limb

Table 16: Inter group Comparison

\begin{tabular}{|c|c|c|c|}
\hline Groups & Symptoms & Reduction & Cured mice \\
\hline Trial & & Day 4 & 2 \\
Standard & Erythema & Day 4 & 2 \\
Control & & Day 5 & 0 \\
\hline Trial & \multirow{3}{*}{ Scaling } & Day 5 & 2 \\
Standard & Day 3 & 3 \\
Control & & Day 4 & 0 \\
\hline Trial & & Day 5 & 2 \\
Standard & Fissure & Day 4 & 2 \\
Control & & Day 6 & 1 \\
Trial & & Day 2 & 1 \\
Standard & Edema & Day 4 & 1 \\
Control & & Day 4 & \\
\end{tabular}




\section{Statistical Analysis}

\begin{tabular}{|l|c|c|c|}
\hline \multicolumn{1}{c}{ Analytical Parameters } & Trial Group & Standard Group & Control Group \\
\hline Sample Size & 6 & 6 & 6 \\
\hline Mean Difference & 1.66 & 1.33 & 0.33 \\
\hline Standard Deviation & 0.81 & 0.81 & 0.51 \\
\hline Standard Error & 0.33 & 0.33 & 0.21 \\
\hline Calculated t value & 5 & 4.00 & 1.58 \\
\hline Table t value & 2.57 & 2.57 & 2.57 \\
\hline Degree of Freedom & 5 & 5 & 5 \\
\hline P or level of Significance & $5 \%$ & $5 \%$ & $5 \%$ \\
\hline Two tailed p Value & 0.017 & 0.010 & 0.174 \\
\hline Inference & Very Significant & Significant & Not Significant \\
\hline
\end{tabular}

Table 18: Paired ' $t$ ' test for Scaling in Inter groups

\begin{tabular}{|l|c|c|c|}
\hline \multicolumn{1}{|c|}{ Analytical Parameters } & Trial Group & Standard Group & Control Group \\
\hline Sample Size & 6 & 6 & 6 \\
\hline Mean Difference & 1.5 & 1.16 & 0.33 \\
\hline Standard Deviation & 1.04 & 0.75 & 0.52 \\
\hline Standard Error & 0.42 & 0.30 & 0.21 \\
\hline Calculated $t$ value & 3.5 & 3.79 & 1.58 \\
\hline Table $t$ value & 2.57 & 2.57 & 2.57 \\
\hline Degree of Freedom & 5 & 5 & 5 \\
\hline Por level of Significance & $5 \%$ & $5 \%$ & $5 \%$ \\
\hline Two tailed $p$ Value & 0.017 & 0.012 & 0.17 \\
\hline Inference & Significant & Significant & Not Significant \\
\hline
\end{tabular}

Table 19: Paired ' $t$ ' test for Fissure in Inter groups

\begin{tabular}{|l|c|c|c|}
\hline \multicolumn{1}{c}{ Analytical Parameters } & Trial Group & Standard Group & Control Group \\
\hline Sample Size & 6 & 6 & 6 \\
\hline Mean Difference & 1.00 & 0.66 & 0.33 \\
\hline Standard Deviation & 0.89 & 0.51 & 0.52 \\
\hline Standard Error & 0.36 & 0.21 & 0.22 \\
\hline Calculated t value & 2.73 & 3.16 & 1.59 \\
\hline Table t value & 2.57 & 2.57 & 2.57 \\
\hline Degree of Freedom & 5 & 5 & 5 \\
\hline Por level of Significance & $5 \%$ & $5 \%$ & $5 \%$ \\
\hline Two tailed p Value & 0.040 & 0.025 & 0.17 \\
\hline Inference & Significant & Significant & Not Significant
\end{tabular}

Table 20: Paired ' $t$ ' test for Edema in Inter groups

\begin{tabular}{|l|c|c|c|}
\hline \multicolumn{1}{|c|}{ Analytical Parameters } & Trial Group & Standard Group & Control Group \\
\hline Sample Size & 6 & 6 & 6 \\
\hline Mean Difference & 0.83 & 1.00 & 0.50 \\
\hline Standard Deviation & 0.40 & 0.63 & 0.54 \\
\hline Standard Error & 0.166 & 0.25 & 0.22 \\
\hline Calculated t value & 5 & 3.87 & 2.23 \\
\hline Table t value & 2.57 & 2.57 & 2.57 \\
\hline Degree of Freedom & 5 & 5 & 5 \\
\hline P or level of Significance & $5 \%$ & $5 \%$ & $5 \%$ \\
\hline Two tailed p Value & 0.004 & 0.011 & 0.075 \\
\hline Inference & Significant & Significant & Not Quite Significant \\
\hline
\end{tabular}

\section{Discussion}

Allergic reactions observed immediately after the sting includes Erythema (redness around the sting site), Inflammation, Tenderness, loss of locomotor activity and Dizziness. Allergic reactions observed hours/ days after the sting includes Itching, Residual redness, A small brown / red damage spot at the sting site, Oedema, Swelling, Bluish discoloration and pus formation at or around the sting site. Female Albino mice were found to be more sensitive than male mice to Honey bee sting. Death of mice usually occurred after 48 hours. Sting reactions are more on female mice. The signs and symptoms were reduced usually after 3 days. Maximum stings were removed by mice themselves within 24 hours as mice always keep themselves clean. One female mouse died on day 3 of trial group. One male mouse died on day 3 of standard group. Two mice died on day 3 of control group; one male and one female due to toxicity of Bee-venom.

The graphs were plotted according to the calculated mean of day 1 and day 7 of the study, which showed significant results of Trial drug and Standard drug. Hence both the drugs can be used in Honey bee sting as a preliminary treatment. Statistical Analysis 
revealed that the Study drug had worked more efficiently on Erythema and Oedema while standard drug worked more efficiently on Scaling and Fissure. There is natural healing mechanism of wound which was observed in control group. Trial drug helps in speedy healing of wound.

Leucoanthocyanin, a chemical constituent present in the bark of Nyagrodh (Ficus benghalensis L.) have anti-inflammatory properties which help in healing of wound. Leucoanthocyanin has anti enzymatic effect against various enzymes out of which hyaluronidase and glucoronidase are two of them present in Honey bee venom. These enzymes are responsible for the spread of venom by increasing the cell wall and capillary permeability. Application of Nyagrodh twak lepa reduces the further spread of venom. Ethanolic and Petroleum ether extracts present in the bark of Ficus benghalensis L. (Nyagrodh) have anti-inflammatory action which helps in wound healing. Nyagrodh has kashaya rasa which is considered Sthambhak in Ayurvedic classics, this property can also help in prevention of spread of venom, as compared to modern texts the bark of Ficus benghalensis L. has haemostatic properties which helps in coagulation of blood.

\section{Erythema}

Graph 1 (Comparison of mean of day 1 and day 7 of Trial group, Standard group and Control group)

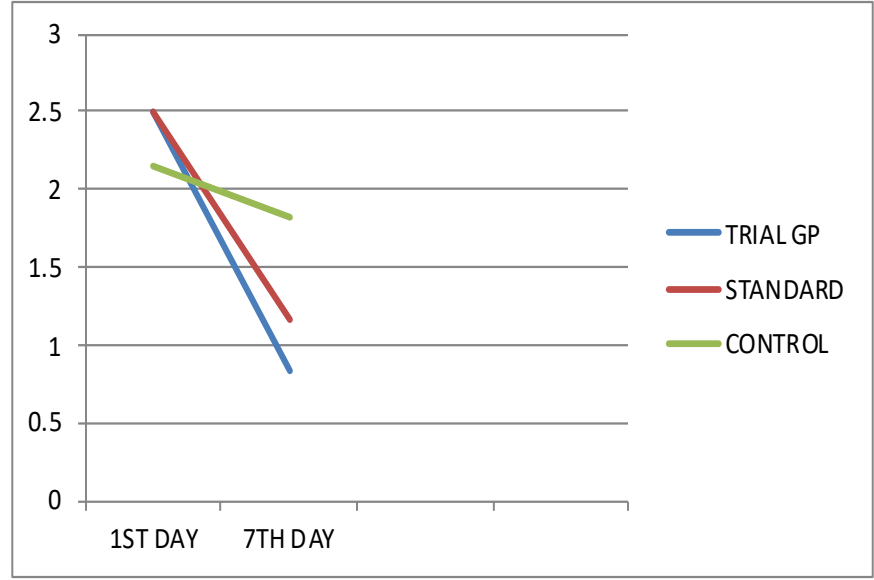

\section{Scaling}

Graph 2 (Comparison of mean of day 1 and day 7 of Trial group,Standard group and Control group)

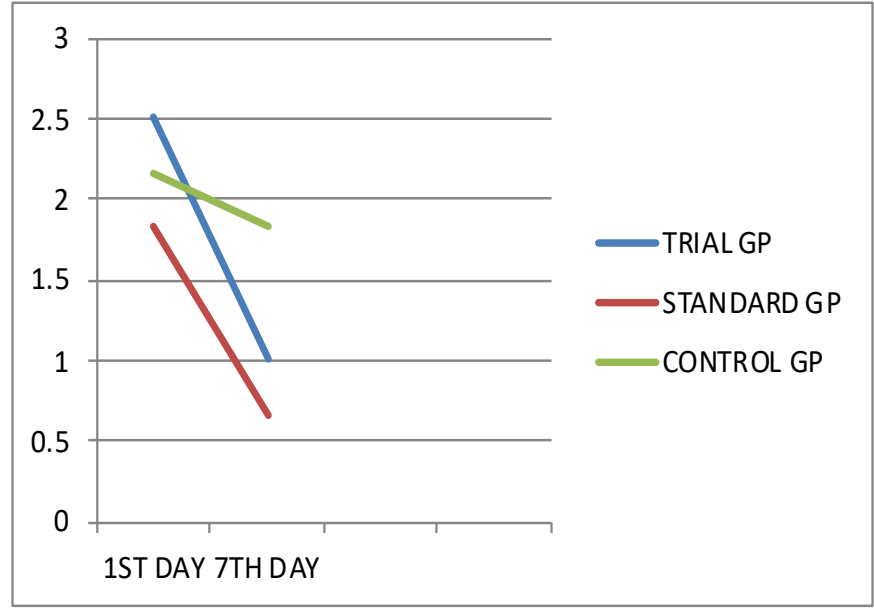

\section{Fissures}

Graph 3 (Comparison of mean of day 1 and day 7 of Trial group, Standard group and Control group)

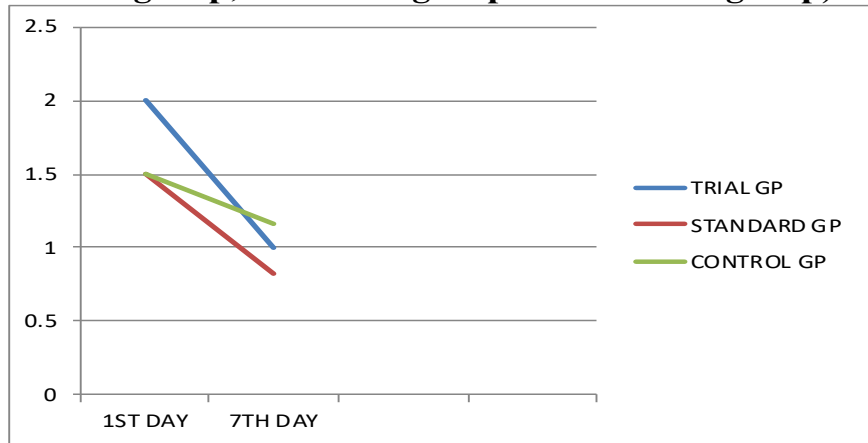

\section{Oedema}

Graph 4 (Comparison of mean of day 1 and day 7 of Trial group, Standard group and Control group)

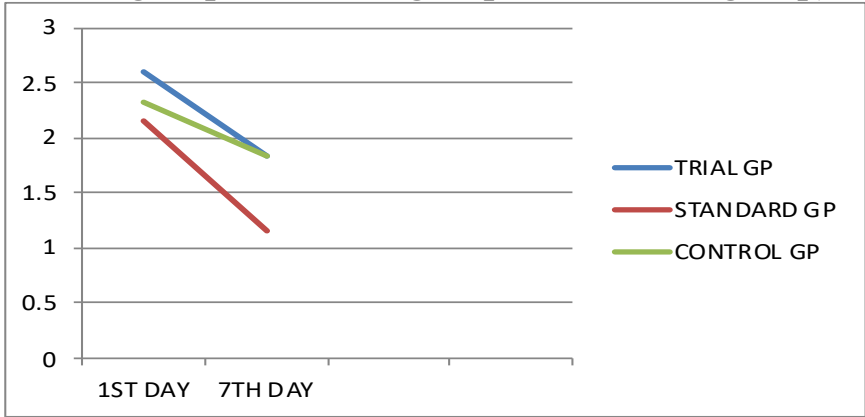

Lepa is one of the treatment modality out of 24 mentioned in Charak Samhita. Vishaghan lepa is adviced to use in $1 / 3$ angula pramaan in thickness which is approximately $0.625 \mathrm{~cm}$. Thickness of human skin is approximately $3-4 \mathrm{~mm}$. Human skin is similar to those mammals in which skin is not covered with fur, hence fur was removed before application of Nyagrodh twak lepa on Albino mice. Shodhan Chikitsa, though the main line of treatment in Visha badha but still small amounts of visha remains in the body which can be removed locally by Lepa application.

\section{Probable mode of action of Nyagrodh twak lepa}

Nyagrodh has sheeta virya which helps in reducing the symptoms like itching (kandu), burning sensation (daha), skin rashes (pidika). Nyagrodh has kashaya rasa and kashaya rasa is considered as Sthambhak, it helps in reducing symptoms like bleeding (rakta straav), erythema on the sting site.(4)

\section{According to biomedical science:}

The chemical constituent i.e., leucoanthocyanin present in the bark of Ficus benghalensis L. (Nyagrodh) possess anti-inflammatory property. Leucoanthocyanin is haemostatic, antiseptic, astringent and reported to improve biological properties of blood vessels. Leucoanthocyanin has anti-enzymatic effect on Xanthine oxidase, Elastase, Collagenase, Hyaluronidase and Glucuronidase. Out of these enzymes Hyaluronidase and Glucosidase are present in bee venom. Glucosidase are the group of members of Glucoronidase enzyme. (5) Nyagrodh twak works against the two enzymes present in the venom of worker 
bee. The bark of Ficus benghalensis L. helps in healing of wound due to the presence of Ethanolic and petroleum ether extracts. These extracts have antiinflammatory action. $(6,7)$

\section{Histopathological changes in skin of Albino Mice-}

- Picture no.1 (trial group female mice): Subcutaneous fat shows foreign body giant cells, mild MNC infiltrate and fibrosis.

\section{Trial group Female Albino mice : Subcutaneous fat shows foreign body giant cells and fibrosis}

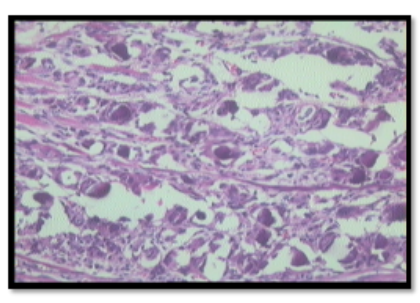

Standard group male albino mice no abnormality detected
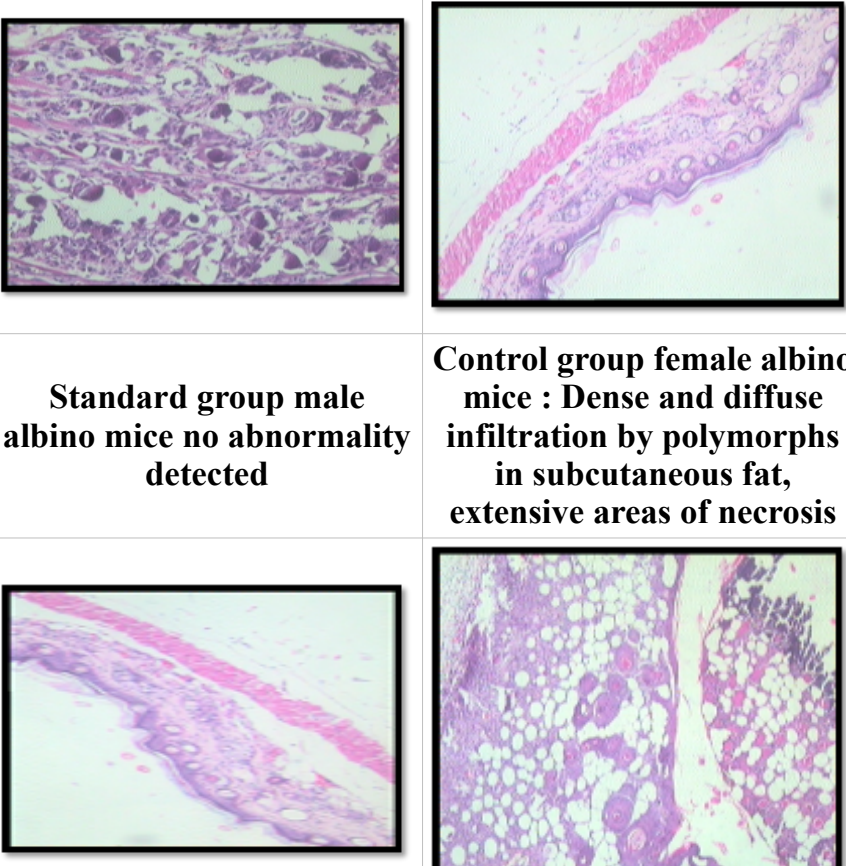

Control group female albino mice : Dense and diffuse infiltration by polymorphs in subcutaneous fat, extensive areas of necrosis

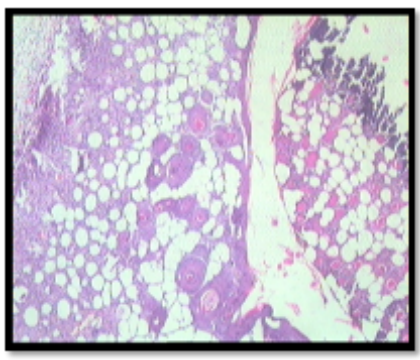

Control group male albino mice : Diffuse infiltration by polymorphs and MNC infiltrate, giant cells, fibroblastic proliferation

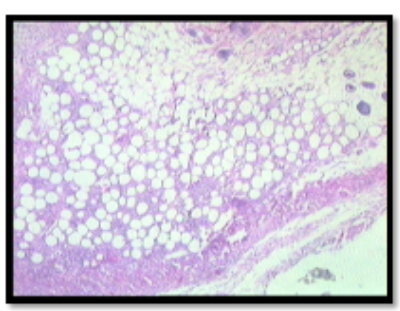

- Picture no.2 (trial group male mice) shows no abnormality detected.

- Picture no.3 (standard group female mice): Subcutaneous fat shows focal areas of histocytic proliferation, occasional giant cells and mild MNC infiltrate.

- Picture no.4 (standard group female mice ): No abnormality detected

- Picture no.5 (control group male mice): Dense and diffuse infiltration by polymorphs in subcutaneous fat with extensive areas of necrosis and areas of fat necrosis.

- Picture no.6 (control group female mice): Subcutaneous fat shows diffuse infiltration by polymorphs and MNC infiltrate, few macrophages and occasional giant cells. There is fibroblastic proliferation.

From histological changes in skin of albino mice after wound healing it was observed that wound that healed with Nyagrodh twak lepa and standard drug have shown almost similar changes while wound that healed without application of any drug(in control group)showed extensive areas of necrosis. Study drug as well as standard drug helped in proper healing of wound hence both the drugs can be used in Honey bee sting.

\section{Conclusion}

Nyagrodh is one of the Panchkshiri Vruksha and Honey bee comes under the category of keeta mentioned in Ayurveda. Nyagrodh twak lepa on albino mice showed decrease in signs and symptoms due to bee venom. It can be concluded from the findings of present study that Nyagrodh twak lepa is effective, helpful in wound healing and can be used in Honey bee sting. The effect of Nyagrodh twak is similar to the standard drug so both the drugs can be used in Honey bee sting. It is economical or free of cost and easily available all over India, hence can be used as an emergency drug for the same.

\section{Reference}

1. Kaviraja Ambika Dutta Shastri, Sushruta Samhita of Acharya Sushruta edited with Ayurveda Tatva Sandipika Hindi commentary, Reprint edition 2011, Chaukhambha Sanskrit Sansthan Varanasi, Part-2, Sushruta Kalpa sthana, 8/35

2. Bramhanand Tripathi; Charak Samhita of Acharya Charaka Volume-1, Chaukhamba Orientalia, Varanasi, Chikitsa Sthana, 23/199

3. Nilam V. Malange, In vivo study of efficacy of Udumbara Twak Lepa in Honey Bee Sting, Yashwant Ayurvedic College PGTRC, Kodoli, Kolhapur, Maharashtra, MD Ayurveda 2008

4. K.C. Chunekar, Bhava Prakash Nighantu of Acharya Bhava Mishra, Indian Materia Medica, Chaukhambha Bharti Academy, Varanasi, Reprint 2013, Vatadi Varga, 501

5. Cheryll Williams, Gums, Resins, Tanins and Essential Oils, Medicinal Plants in Australia, Vol 2

6. Vikas V Patil, Vijay R Patil, Ficus benghalensis linn - An overview, International Journal of Pharma and Bio sciences, 2010, Vol 1 (2),

7. Baby Joseph, S. Justin Raj, Pharmacognostic and traditional properties of Cissus quadrancularis linn -An overview International Journal of Pharma and Bio sciences, Vol 1 (4)/ Oct - Dec 2010, 251/246-253. 